\section{Discussion}

The transplanted human kidney satisfies the criteria for denervation put forth by Quinby (1916) and emphasized by Bricker et al. (1958). Earlier reports have indicated that the sympathetic nervous system may play a part in the regulation of the secretion of renin by the cells of the juxtaglomerular apparatus. The renal nerves (Taquini et al., 1964 ; Tobian et al., 1965) and circulating catecholamines (Gordon et al., 1966) have both been implicated as mediators of this regulatory mechanism. The present findings indicate that the normal "renin response" seen with postural change apparently remains intact after denervation of the kidney. Previous studies have cast doubt upon the contention that circulating catecholamines stimulate renin secretion. Laragh et al. (1960) were unable to demonstrate elevation of the aldosterone secretory rate with infusion of catecholamines. This is indirect evidence that renin secretion did not rise in his subjects. Wathen et al. (1965) were not able to stimulate renin release in dogs with intravenous catecholamine administration, though perfusion of catecholamines direct into the renal artery did increase renin secretion.

Studies performed upon persons with idiopathic orthostatic hypotension who do not display the normal orthostatic increase in sympathetic activity have suggested that low circulatory catecholamine levels do play a part in the abnormal renin secretory pattern seen in these patients (Gordon et al., 1966). Hall and Hökfelt (1966) confirmed these findings; however, they could not reproduce this phenomenon in normal subjects given adrenergic blocking agents.

Conflicting experimental findings must leave the question of sympathetic mediation of the renin-angiotensin-aldosterone system an open one. Lewis et al. (1966) have previously shown that normal sodium-regulating mechanisms persist after human renal denervation and transplantation.

The present results support the concept that homoeostatic mechanisms involving renin secretion are intact after renal denervation. While this finding does not disprove the existence of some association between the sympathetic nervous system and the renin-angiotensin-aldosterone system, it suggests that other mechanisms are also operative.

\section{Summary}

Peripheral venous renin levels were measured in three homotransplant patients in the upright and recumbent positions. The normal pattern of elevation of the renin level in the upright position and depression in the recumbent position was seen. It is concluded that a mechanism independent of the renal nerves is operative in regulating the postural change in renin secretion by the kidney.

Dr. Hickler is a Career Development Awardee, U.S. Public Health Service, 5K3-HE-14903. Dr. Lewis performed his work during the tenure of a Postdoctoral Fellowship awarded by the National Heart Institute (NIH, U.S. Public Health Service). Dr. Blaufox performed this work during the tenure of an Advanced Research Fellowship of the American Heart Association.

\section{REFERENCES}

Barajas, L. (1964). Lab. Invest., 13, 916.

Blaufox, M. D Birbari A Hickler, R. and Merrill, J. P. (1966). New Engl. f. Med. To be published.

Boucher, R., Veyrat, R., de Champlain, J., and Genest, J. (1964). Can. med. Ass. f., 90, 194.

Bricker, N. S., Straffon, R. A., Mahoney, E. P., and Merrill, J. P. (1958) f. clin. Invest., 37, 185 .

Conn, J. W., Rovner, D. R., and Cohen, E. L. (1965). Ann. intern. Med., 63, 266.

Edelman, R., and Hartroft, P. M. (1961). Circulat. Res., 9, 1069.

Gordon, R. D., Kuchel, O., Island, D. P., and Liddle, G. W. (1966). F. clin. Invest., 45, 1016.

Hall, K., and Hökfelt, B. (1966). Acta med. scand., 179, Suppl. No. 445, p. 397.

Laragh, J. H., Angers, M., Kelly, W. G., and Lieberman, S. (1960). 尹ु. Amer. med. Ass., 174, 234.

Lewis, E., Blaufox, M. D., Jagger, P., Lauler, D., Qureshi, E., and Merrill, J. P. (1966).

Quinby, W. C. (1916). f. exp. Med., 23, 535.

Taquini, A. C., Blaquier, P., and Taquini, A. C., jun. (1964). Canad. med. Ass. F., 90, 210.

Tobian, L., Braden, M., and Maney, J. (1965). Fed. Proc., 24, 405.

Wathen, R. L., Kingsbury, W. S., Stouder, D. A., Schneider, E. G., and Rostorfer, H. H. (1965). Amer. F. Physiol., 209, 1012.

\title{
Low-dosage Oral Ethynodiol Diacetate Tablets for Long-term Contraception in Indian Women
}

\author{
PRABHAKER N. SHAH,* M.D., F.C.P.S.
}

From field studies in Puerto Rico, Mexico, and Ceylon it has become evident that, contrary to all predictions by the experts, the poorly educated women of low socio-economic status accept oral contraception enthusiastically and successfully (Rice-Wray, 1957 ; Rice-Wray et al., 1965 ; Chinnatamby, 1965 ; Rao, 1965). In that respect, as I reported earlier (Shah, 1965, 1966), Indian women belonging to this class of society are no different from their counterparts in other parts of the world. In fact, once these women know that an oral "pill " is available, it is difficult if not impossible to make them use any other method of birthspacing.

Since the contraceptive efficiency of the various synthetic progestogens in different geographical populations is no longer in dispute, current research is directed towards finding an oral contraceptive that would have a low incidence of side-reactions

- Department of Endocrinology, Indian Cancer Research Centre, Parel, Bombay, India. and a good cyclic control in each population, and towards assessment of the lowest effective dosage for each compound for successful contraception. Such low-dosage tablet, so far as developing countries like India are concerned, would have two added advantages: (1) reduce the cost of the pill, and (2) minimize its inhibiting effect on lactation in women in whom breast-feeding is a necessity for reasons of economy. The purpose of this paper is to report a few aspects arising out of our experience related to the administration of low-dosage ethynodiol diacetate in "combined" or "sequential" schedules for contraception in Indian women.

\section{Present Series}

A total of 380 fertile women aged 18 to 35 , with an average age of 24.2 years, participated in the trial. Analysis of the data of these women indicated that $62 \%$ were illiterate or had had 
very little formal education, while about $73 \%$ belonged to a group whose average income was less than the national average ( 17 per annum). An important point that needs to be emphasized is that approximately $70 \%$ of these women, who had never previously used any contraceptive, found a method of birth control that was acceptable and satisfactory.

Of the 380 women 160 were on the combined schedulethat is, 0.25 or $0.5 \mathrm{mg}$. of ethynodiol diacetate and $0.1 \mathrm{mg}$. of mestranol daily for 20 days, starting from day 5 of a menstrual cycle; the remaining 220 women were on the sequential schedule-that is, $0.1 \mathrm{mg}$. of mestranol daily for the first 10 days, starting from day 5 , and then $0.1 \mathrm{mg}$. of mestranol plus 0.5 mg. of ethynodiol diacetate for the remaining 10 days (Table I). This sequential schedule was conceived and employed by me in 1963, and the two differently coloured tablets, bottled in the simplest fashion like a double-decker omnibus, have never caused any confusion at all with our illiterate women.

\begin{tabular}{|c|c|c|c|}
\hline \multicolumn{2}{|l|}{$\begin{array}{c}\text { Schedule } \\
\text { of } \\
\text { Administration }\end{array}$} & $\begin{array}{c}\text { Compounds } \\
\text { Used } \\
\text { per Tablet }\end{array}$ & $\begin{array}{l}\text { Abbreviations for } \\
\text { Schedule and } \\
\text { Tablet Used }\end{array}$ \\
\hline Combined .. & & $\begin{array}{l}0.25 \mathrm{mg} . \text { ethynodiol diacetate }+0.1 \mathrm{mg} \text {. } \\
\text { mestrano) }\end{array}$ & CB (0.25 mg.) \\
\hline $\quad \cdots$ & . & $0.5 \mathrm{mg}$. ettynodiol diacetate $+0.1 \mathrm{mg}$. & CB (0.5 mg.) \\
\hline Sequential $10 / 10$ & . & $\begin{array}{l}0.1 \mathrm{mg} \text {. mestranol } / 0.5 \mathrm{mg} \text {. ethynodiol } \\
\text { diacetate }+0.1 \mathrm{mg} . \text { mestranol }\end{array}$ & SQ (0.5 mg.) \\
\hline
\end{tabular}

The aggregate total number of cycles of treatment in 380 women till April 1960 was 4,262 (4,200 months of use) and the cycles of study for each schedule are as shown in Table II. Although in our preliminary findings complete contraceptive effect was observed with the combined schedule at the dose level of $0.25 \mathrm{mg}$. (CB $0.25 \mathrm{mg}$.), this low-dosage treatment was discontinued because the cyclic control was not as satisfactory as it was with the $0.5-\mathrm{mg}$. dosage (see Table IV). Therefore, except for comparative studies of short-term side-reactions and of the effects on the menstrual cycle, the cycles of this lowdosage medication (CB $0.25 \mathrm{mg}$.) are not considered in this report on the use and effectiveness of ethynodiol diacetate.

\begin{tabular}{|c|c|c|c|c|c|}
\hline \multirow{2}{*}{\multicolumn{2}{|c|}{$\begin{array}{c}\text { Schedule of } \\
\text { Administration } \\
\text { and } \\
\text { Tablet Used }\end{array}$}} & \multirow{2}{*}{$\begin{array}{l}\text { No. of } \\
\text { Cycles }\end{array}$} & \multirow{2}{*}{$\begin{array}{l}\text { No. of } \\
\text { Women }\end{array}$} & \multicolumn{2}{|c|}{ Pregnancies } \\
\hline & & & & $\begin{array}{c}\text { Tablet } \\
\text { Failure }\end{array}$ & $\begin{array}{l}\text { Patient } \\
\text { Failure }\end{array}$ \\
\hline $\begin{array}{l}\text { CB (0.25 mg.) } \\
\text { CB (0.5 mg.) } \\
\text { SQ ( } 0.5 \text { mg.) }\end{array}$ & $\because$ & $\begin{array}{r}351 \\
1,700 \\
2,211 \\
\end{array}$ & $\begin{array}{r}50 \\
110 \\
220 \\
\end{array}$ & $\begin{array}{c}\mathrm{Nil} \\
\# \\
\#\end{array}$ & $\begin{array}{l}\mathrm{Nil} \\
1^{*} \\
\mathrm{Nil}\end{array}$ \\
\hline Total & $\ldots$ & 4,262 & 380 & & \\
\hline
\end{tabular}

\section{Results}

The pregnancy-rate figures (Table II) show that both the schedules employing $0.5 \mathrm{mg}$. of ethynodiol diacetate are virtually $100 \%$ effective, since only one out of 330 women on medication became pregnant. This particular woman, however, had a short cycle of 20 days and became pregnant on day 5 or 6 of the first treated cycle, presumably before the drug could inhibit ovulation. She was told about this possibility and was advised to use other conventional methods during the first cycle. However, her husband was uncooperative and was against the use of any method.

A really good marker for the preference of any of these lowdosage schedules is the number of women withdrawing from continuous medication because of side-reactions connected with the schedule. Three out of 50 women on the $0.25-\mathrm{mg}$. combined schedule gave up because of persistent break-through bleeding in three consecutive cycles (Table III).
TABLE III.-Comparative Studies on Oral Contraceptives in Indian Women

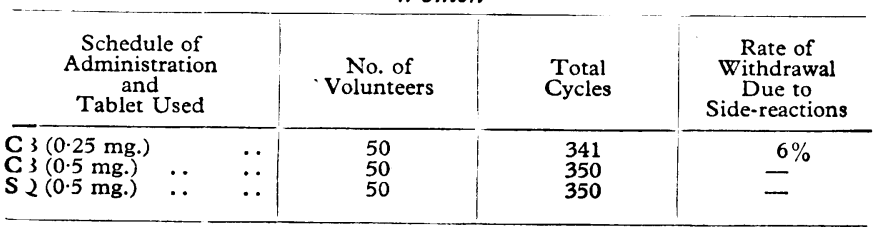

For the objective evaluation of other short-term unpleasant side-effects parallel studies were carried out in an unselected group of 50 women for each schedule given for six months or seven cycles. The various indices of study, with their frequency, are shown in Table IV. From these data it appears that with the sequential method frequency of nausea is minimal and the cyclic control is better than that seen with the combined schedule employing $0.5 \mathrm{mg}$. of ethynodiol diacetate. Another advantage of the sequential over the combined schedule is manifested in the change in menstrual flow in the post-medication cycles. It is quite clear that the sequential method is rather less potent in depressing the menstrual flow. Further, no change in flow in the post-medication cycles was observed in $68 \%$ with the sequential as compared with $32.6 \%$ with the combined method. These findings correlate very well with our post-medication histological findings of the endometrium; the most abundant and normal-looking endometrium was seen after the sequential schedule (Shah, unpublished data). In short, in our hands the sequential medication seems to have produced the most physiological type of endometrium and withdrawal bleeding. As stated elsewhere (Shah, 1965), Indian women, irrespective of their education, for several generations have been conditioned to the idea that regularity of the cycle with a good flow equates with the degree of health of a woman; it would take some time before they accept without great concern the scanty flow that occurs commonly after all the combined schedules.

TABLE IV.-Comparative Studies of Side-reactions and Effects on

\begin{tabular}{|c|c|c|c|c|}
\hline & & \multicolumn{3}{|c|}{ Tablet Administered } \\
\hline & & $\mathrm{CB}(0.25) \mathrm{mg}$. & CB (0.5) mg. & $\mathrm{SQ}(0.5) \mathrm{mg}$. \\
\hline No. of women and total cycles & & $50 / 341$ & $50 / 350$ & $50 / 350$ \\
\hline 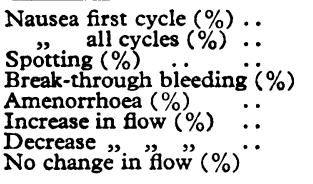 & $\begin{array}{l}\because \\
\because \\
\because \\
\because \\
\cdots\end{array}$ & $\begin{array}{l}4 \cdot 0 \\
0 \cdot 6 \\
3 \cdot 2 \\
6 \cdot 6 \\
1 \cdot 8 \\
2 \cdot 6 \\
8 \cdot 5 \\
88 \cdot 9\end{array}$ & $\left.\begin{array}{r}12 \cdot 0 \\
2 \cdot 0 \\
1 \cdot 1 \\
2 \cdot 0 \\
1 \cdot 1 \\
15 \cdot 1 \\
52 \cdot 3 \\
32 \cdot 6\end{array}\right\} 4 \cdot 2$ & $\left.\begin{array}{c}2 \cdot 0 \\
0 \cdot 9 \\
0 \cdot 3 \\
2 \cdot 3 \\
\frac{6 \cdot 0}{26 \cdot 0} \\
68 \cdot 0\end{array}\right\} 2 \cdot 6$ \\
\hline
\end{tabular}

Mention must also be made of the low incidence of breast discomfort under both these schedules. This may possibly be due to the fact that these women of low socio-economical level have, to start with, flabby breasts because of the prolonged lactation following previous childbirths.

\section{Effect on Lactation and the Baby}

Of the 330 women 156 were lactating-132 were lactating and spontaneously menstruating before medication was started, and in 24 menstruation was induced by giving hormones before putting them on any schedules. Of the 50 lactating women on the combined schedule none complained of less secretion in the post-medication period, while 2 of the 106 women under the sequential therapy definitely felt that milk secretion was decreased-one in the second cycle and the other in the third cycle of medication. Both these women, however, continued medication and there was no total suppression of milk. All the children of these 156 mothers taking oral contraceptives were periodically examined, and no deleterious effect on their growth or any sign of oestrogenization was found. 


\section{Effect on Liver Function}

Since Indian women, by virtue of their poor build and nourishment (average weight $90 \mathrm{lb}$. ; $40.8 \mathrm{~kg}$.), are thought to have livers that are more vulnerable, liver-function studies were made on an unselected group of 10 women who were on both these schedules for 13 or more cycles. Two sets of standard liver-function tests were performed in each woman. For the hepatocellular function serum levels of glutamic oxaloacetic transaminase and glutamic pyruvic transaminase were estimated. For the canalicular function serum alkaline phosphatase and 5-nucleotidase were determined. Similar tests were performed on a control series consisting of 24 apparently healthy women of child-bearing age belonging to low socio-economic levels. As reported elsewhere (Shah, 1965, 1966), these various criteria of liver function did not reveal any evidence to suggest that the tablets interfered in any way with the specific function of the liver.

\section{Discussion}

The possibility that cyclic administration of certain oestrogens - for example, mestranol alone in adequate dose-for long-term contraception can be used has been studied (Goldzieher et al., 1964). However, on this therapy, break-through ovulation is known to occur occasionally (Walker, 1965). Administration of oestrogen alone for this purpose is rejected for other reasons -namely, (1) cycle control is not satisfactory, and (2) there is a tendency to heavy withdrawal-bleeding with the continued use. A more satisfactory oral contraceptive tablet, therefore, would be one that contained an adequate dosage of oestrogenic compound to suppress ovulation, fortificd with a small dose of progestogen to regulate the menstrual cycle. The probable mode of contraceptive effect of such sequential approach is by inhibiting both follicle-stimulating hormone and luteinizing hormone. On the other hand, the probable mode of effect of a classical combined pill is either by suppression of the formation and/or release of luteinizing hormone or by rendering the cervical mucus hostile to sperm penetration (Diczfalusy, 1965).

All three preparations reported in this paper contained the constant amount of mestranol $(0.1 \mathrm{mg}$.) that would inhibit ovulation but had varying proportions of ethynodiol diacetate or differed in mode of administration. Looked at from various aspects, our results of sequential medication with $0.5 \mathrm{mg}$. of ethynodiol diacetate should encourage anyone to try this method with a smaller dosage- $0.25 \mathrm{mg}$. or even $0.1 \mathrm{mg}$. Besides minimal side-reactions and a menstrual flow simulating premedication flow, the sequential therapy would be cheaper than the combined medication, since the progestogen required for the former schedule would be one-half to one-tenth the amount required for the latter.

Our preliminary observations' with the sequential schedule employing $0.25 \mathrm{mg}$. of ethynodiol diacetate are interesting, but no definite conclusions can be made until the total number of cycles of study is such as to assess the use and effectiveness of this schedule. It seems that the data of Mears (1965), Goldzieher (1965), and Behrman (1965) are in conflict with some of ours with respect to the contraceptive efficiency of the sequential method. This is probably due to the difference in the sequential regimen and the dose of oestrogen employed. The sequential schedule reported by these workers is $15 / 5$, and the failure of the schedule is explained on the basis of the break-through ovulation. However, under sequential 11/10 schedule Mears (1965) found no pregnancy; but the series under trial was small and only a few women had completed more than two cycles of medication. Our data, based on a series of 220 women taking the sequential $10 / 10$ schedule for 2,211 cycles, emphasize the virtual $100 \%$ contraceptive efficiency. Again, as seen from our data, the observation of Mears (1965) that there appeared to be an increased risk of pregnancy when women were transferred from the combined schedule to the sequential schedule cannot be substantiated. For example, of the total 220 women on sequential $10 / 10$ schedule 101 , after having been transferred from various combined schedules, have already completed 1,022 cycles, but not a single pregnancy among them so far has been recorded (Tables V and VI). Furthermore, it appears that, after transference to the sequential schedule, menstrual flow improved in the women of both series who were initially on a combined schedule comprising ethynodiol diacetate or norethisterone acetate (Table VII).

\begin{tabular}{|c|c|c|c|c|}
\hline \multicolumn{2}{|c|}{ No. of Women } & Women Months & & No. of Pregnancies \\
\hline \multicolumn{2}{|c|}{101 (transferred) } & $\begin{array}{r}1,096 \\
943\end{array}$ & \multicolumn{2}{|r|}{$\begin{array}{c}\text { Nil } \\
\#\end{array}$} \\
\hline \multicolumn{2}{|c|}{220} & 2,039 & & \\
\hline \multicolumn{5}{|c|}{ TABLE VI.-Details of the Transferred Series of Women (101) } \\
\hline $\begin{array}{l}\text { No. of } \\
\text { Women }\end{array}$ & \multicolumn{2}{|c|}{$\begin{array}{l}\text { Initial } \\
\text { Tablets } \\
\text { Used }\end{array}$} & $\begin{array}{l}\text { No. of Cycles } \\
\text { on Initial } \\
\text { Tablets }\end{array}$ & $\begin{array}{c}\text { No. of Cycles } \\
\text { on Transferred } \\
\text { Tablets }\end{array}$ \\
\hline $\begin{array}{l}52 \\
49\end{array}$ & \multicolumn{2}{|c|}{$\begin{array}{l}0.5 \text { mg. ethynodiol diacetate } \\
\text { (ED)+0.1 mg. mestranol } \\
4 \text { mg. norethisterone acetate } \\
\text { (NA)+0.05 mg. ethinyl } \\
\text { oestradiol (EE) Anovlar. }\end{array}$} & $\begin{array}{l}360 \\
346\end{array}$ & $\begin{array}{l}674 \\
348\end{array}$ \\
\hline Total 101 & & & & 1,022 \\
\hline
\end{tabular}

TABLE VII.-Effect on Menstrual Flow on Changing from Combined to Sequential (10/10) Schedule

\begin{tabular}{|c|c|c|c|c|}
\hline \multirow[b]{2}{*}{$\begin{array}{l}\text { Composition of the } \\
\text { tablet }\end{array}$} & \multicolumn{2}{|c|}{ Combined $\rightarrow$ Sequential } & \multicolumn{2}{|c|}{ Combined $\rightarrow$ Sequential } \\
\hline & $\begin{array}{c}0.5 \mathrm{mg} . \mathrm{ED}+ \\
0.1 \mathrm{mg} . \\
\text { mestranol }\end{array}$ & SQ (0.5 mg.) & $\begin{array}{l}4 \text { mg. NA+ } \\
0.05 \mathrm{mg} . \mathrm{EE}\end{array}$ & SQ (0.5 mg.) \\
\hline $\begin{array}{l}\text { No. of women and } \\
\text { total cycles }\end{array}$ & $43 / 301$ & $43 / 276$ & $50 / 346$ & $47 / 307$ \\
\hline $\begin{array}{l}\text { Increase in flow (\%) } \\
\text { Decrease "\#, ", } \\
\text { No }\end{array}$ & $\begin{array}{l}17 \cdot 6 \\
52 \cdot 4 \\
30 \cdot 0\end{array}$ & $\begin{array}{l}37 \cdot 7 \\
14 \cdot 1 \\
48 \cdot 2\end{array}$ & $\begin{array}{r}5 \cdot 2 \\
67.9 \\
26.9\end{array}$ & $\begin{array}{l}38 \cdot 1 \\
14 \cdot 6 \\
47 \cdot 3\end{array}$ \\
\hline
\end{tabular}

On the other hand, there is no doubt that much still remains to be learnt about the population differences vis-à-vis dosage of oral contraceptives. However, the single fact emerging out of our study is that if an adequate dose of oestrogen is constantly used throughout the cycle the smallest possible dose of expensive progestogen is probably enough to ensure virtually $100 \%$ contraceptive efficiency and maximum acceptability of the sequential schedule.

\section{Summary and Conclusions}

A two-and-a-half-year study of 330 Indian women using low-dosage oral contraceptive tablets during 4,262 cycles is presented.

Comparison of the side-reactions and the effects on the menstrual cycle for combined and sequential schedules with $0.5 \mathrm{mg}$. of ethynodiol diacetate indicates some advantages of the sequential over the combined medication. The sequential therapy used in 10/10 tablets for oral contraception is efficient and acceptable in the group of Indian women of the low socioeconomic level.

The effects of short-term and long-term administration of low-dosage oral tablets do not preclude the method from trials in highly fertile young women of India.

I wish to acknowledge the generous supply of Anovlar received from Schering Asia GmBH, of various formulations of ethynodiol diacetate provided by G. D. Searle \& Co. Ltd., and the unstinted enthusiasm of my team of social workers, in particular Mrs. Neela Sathe, without whose co-operation this work would not have been possible. Grateful acknowledgement is also due to Mr. V. 
Balkrishnan for help in the statistical analysis of the data on liverfunction tests.

ADDENDUM.-I have realized since this paper was written that my assumption concerning the lower cost of sequential oral contraceptives may be incorrect. It is possible that the increased cost of packaging and ensuring that the right tablets are always packed may more than offset any saving in cost of materials. If this is the case, the most economical oral contraceptive for a national family planning programme may still be a low-dose combination tablet.

\section{REFERENCES}

Behrman, S. J. (1965). In Proceedings of the Symposium on Agents Affecting Fertility, edited by C. R. Austin and J. S. Perry, p. 237. Biological Council. Churchill, London.
Chinnatamby, S. (1965). In Proceedings of the Seminar on Modern Contraceptive Devices, edited by B. N. Purandare. Bombay.

Diczfalusy, E. (1965). Brit. med. f., 2, 1394.

Goldzieher, J. W. (1965). Quoted by Mears (1965).

- Livingston, N. B., Martinez Manautou, J., and Moses, L. E. (1964) In Proceedings of the Seventh Conference of the International Planned Parenthood Federation, Singapore, edited by G. W. Cadbury, H. D. Connollv, K. V. Earle, and A. S. Parkes. Excerpta Medica Foundation, Amsterdam.

Mears, E. (1965). Proceedings of the Symposium on Agents Affecting Fertility, edited by C. R. Austin and J. S. Perry, p. 233. Biological Fertility, edited by C. R. Aus

Rao, P. V. (1965). In Proceedings of the Seminar on Modern Contraceptive Devices, edited by B. N. Purandare.

Rice-Wray, E. (1957). In Proceedings of the Symposium on 19-Nor Progestational Steroids. Searle, Chicago.

- Cervantes, A., Gutiérrez, J., Rosell, A. A., and Goldzieher, J. W. (1965). Metabolism, 14, 451.

Shah, P. N. (1965). In Proceedings of the Seminar on Modern Contraceptive-Devices, edited by B. N. Purandare. Bombay.

(1966). 7. Obstet. Gynaec. India. In press.

Walker, R. (1965). In Proceedings of the Symposium on Recent Advances in Ovarian Synthetic Steroids, edited by R. P. Shearman. Searle, Sydney.

\section{Medical Memoranda}

\section{"Collagen Disease" due to Carbamazepine (Tegretol)}

\section{Brit. med. F., 1966, 2, 1434}

The toxic effects of carbamazepine (Tegretol) hitherto reported included drowsiness, dry mouth, nausea, and vomiting, which appear to be infrequent and not severe. There have been two cases of jaundice, which recovered, and two fatal cases of aplastic anaemia. Generalized erythema, resolving without sequelae on cessation of the drug, occurs in an estimated 3-4\% of those taking it, and one case of photosensitivity has been reported. Coombes (1965) reported a case of Stevens-Johnson syndrome from this cause. The following case report illustrates another reaction affecting chiefly the skin, which appears to have been provoked by carbamazepine.

\section{CASE Report}

A woman aged 63 was seen in December 1963 with a nummular, partly lichenified eczema of nine months' duration involving the neck, the backs of the forearms, and the left wrist. Subsequently, other patches appeared elsewhere on the trunk and limbs. There were good reasons for thinking that the eruption was due to stress, and it settled gradually with rest, sedation, and topical application of steroid creams and fractional $x$-ray therapy. All signs and symptoms had gone by March 1964 . Her only previous dermatological history was of pruritus ani 10 years earlier, for which she received an injection, which was followed by a widespread rash persisting for several months.

Towards the end of 1964 she experienced intermittent pain on the right side of the face, which was not relieved by dental extractions and for which no other cause could be found. During September and October 1965 she took carbamazepine, $200 \mathrm{mg}$. t.i.d., continuing on $200 \mathrm{mg}$. b.d. in November and December. Her skin had remained well until the middle of September 1965 . On 1 October she was seen again with an eruption which was identical in character and similar in distribution to her previous eczema, and which responded rapidly to similar treatment within four weeks. She remained well apart from slight loss of weight and indigestion until, early in January 1966, she suddenly developed a non-irritant rash of entirely different character, associated with malaise and pain in the right scapular region. On 6 January she presented a discrete eruption of a peculiar dusky heliotrope colour affecting the eyelids, which were slightly oedematous, eyebrows, backs of the elbows, lumbo-sacral region, and wrists. On the dorsal surfaces of the hands and carpometacarpal and interphalangeal joints the lesions were slightly infiltrated and covered with fine superficial grey scales. The same heliotrope colour was found on the paronychial folds, where capillary dilatation could be recognized with a lens. There was no muscular weakness or wasting, but the clinical picture suggested a diagnosis of either lupus erythematosus or dermatomyositis. All treatment was stopped and she was admitted for intensive investigation, particularly in view of the fact that dermatomyositis at this age is often associated with an internal malignant neoplasm.

Clinical examination by a general physician and a gynaecologist revealed no abnormality apart from the skin. Blood count, E.S.R., midstream urine, serum proteins, S.G.O.T., and urinary creatine were all normal. Skiagram of chest, intravenous pyelogram, and barium-swallow, meal, follow-through, and enema revealed no abnormality.

Before the end of January the rash had completely disappeared and the patient was free from all symptoms. She remained so until 5 March, when the rash, malaise, and pain in the back all recurred. On 4 March she had taken one tablet of carbamazepine and continued on $200 \mathrm{mg}$. t.i.d. until 7 March. When seen on $10 \mathrm{March}$ the eruption was similar in all respects to that which she had presented in January. The symptoms and signs again resolved spontaneously within three weeks.

\section{Comment}

The patient had experienced two previous episodes of skin disease, and was perhaps for that reason more liable than usual to react in this way. The recent eruption, however, was totally different in character and was certainly not a recurrence of the endogenous eczema observed in 1963-4 and in October 1965. Its spontaneous recovery on stopping the drug and prompt recurrence on resuming it, followed again by spontaneous recovery, leave no doubt that it was caused by carbamazepine.

Lupus erythematosus, or a syndrome closely resembling it, has been reported in association with the ingestion of hydrallazine, derivatives of hydantoin, griseofulvin, sulphonamides, and penicillin. To this list carbamazepine must now be added.

I am grateful to Dr. A. W. Galbraith, of the Medical Department of Geigy Ltd., who kindly supplied me with the relevant literature.

J. R. Simpson, M.B., M.R.C.P., Consultant Dermatologist, Royal Devon and Exeter Hospital.

\section{REFERENCR}

Coombes, B. W. (1965). Med. F. Aust., 1, 895. 